\title{
Contributing to the Asia Pacific Journal of Management
}

\author{
David Ahlstrom
}

Published online: 24 April 2012

(C) Springer Science+Business Media, LLC 2012

At the Asia Pacific Journal of Management (APJM) part of our mission is to help prospective authors, particularly those new to the academic management field, develop their work and publishing skills so as to further build management and organizational research in Asia (Bhagat, McDevitt, \& McDevitt, 2010; Fang, 2010; Ahlstrom, 2010a). To that end, since 2010, APJM has been running a series of articles to assist authors with the many challenges of publishing in mainstream management journals such as APJM (e.g., Ahlstrom, 2010a, b, 2011a, b). Prospective authors who want to know more about the research and publishing process (particularly for $A P J M$ ) should read these editorial articles and other helpful works cited to become more familiar with APJM's content, paper organization, aims and scope, and style. APJM desk rejects a good number of papers. Many of these desk rejections probably could have been avoided if authors were more familiar with what APJM typically publishes (Ahlstrom, 2012), its aims and scope (Ahlstrom, 2011a), and were careful to read the editorials mentioned here and the works cited therein (e.g., Abrahamson, 2008; Colquitt \& Ireland, 2009; Cummings \& Frost, 1985, 1995; Huff, 1999, 2008; Van de Ven, 2007).

In 2010, APJM published three editorial articles with some recommendations on publishing in the journal (Ahlstrom, 2010a), steering clear of several common mistakes that normally lead to desk rejections, such as failing to specify the paper's

Asia Pacific Journal of Management would like to announce that the 2008 publication in APJM by Kenneth S. Law, Chi-Sum Wong, Guo-Hua Huang, and Xiaoxuan Li titled "The effects of emotional intelligence on job performance and life satisfaction for the research and development scientists in China" was awarded the 2011 Mike Peng Best Paper Award by Springer Publishing. The Mike Peng Best Paper Award is given annually to an excellent article published in past years at APJM. The 2012 award will be announced at the Asia Academy of Management Conference to be held on December 10-12, 2012 at Korea University in Seoul, Korea. APJM would also like to thank the editors of this current Special Issue on Leadership in Asia, Rico Lam of the University of Macau, Xu Huang of The Hong Kong Polytechnic University, and Dora Lau of The Chinese University of Hong Kong for their hard work on this APJM Special Issue. Thanks also go to Rae Pinkham and Marc Ahlstrom of Burlington County College for their editorial and research assistance.

D. Ahlstrom $(\bowtie)$

Department of Management, The Chinese University of Hong Kong, Shatin, NT, Hong Kong

e-mail: ahlstrom@baf.msmail.cuhk.edu.hk 
contributions to theory and empirical evidence (Ahlstrom, 2010b), and avoiding the submission of "how-to" articles targeted at managers and consultants (Ahlstrom, 2010c). In 2011 three more editorial articles were published that further clarified APJM's aims and scope (Ahlstrom, 2011a), provided general tips on organizing an empirical paper (Ahlstrom, 2011b), and summarized these and other helpful books and articles for prospective authors (Ahlstrom, 2011c). Authors should take care to read these (and future) editorials and commentaries from the journal editors and other authors as they provide recommendations and resources concerning the research and publishing process.

\section{Contributions}

Finally, it bears repeating that a continuing problem with the submissions we receive at $A P J M$ is that many authors are still failing to specify the contributions of their papers. Like the land in a crowded city, academic "real estate" is both scarce and valuable, and papers usually need to contribute new or improved knowledge to the field of management and organizations. This means that authors need to state the contributions of their papers clearly - in the introduction of the paper and again in the discussion section (see Meyer, Estrin, Bhaumik, \& Peng, 2009; Rynes et al., 2005). Just testing what is already well known without providing clear contributions or improved information or evidence for the field is usually cause for rejection in good academic journals (e.g., Kilduff, 2007; Rynes, 2002; Rynes et al., 2005).

For example, we received a manuscript at APJM that provided a thorough literature review about pay for performance and some gender issues in motivation. The paper went on to explain that there had been much researched on these topics including at least one major meta analysis. The paper then provided two (out of four) hypotheses that tested the relationships that were already very well documented by that meta analysis and other research. Basically, the paper simply tested what was already very well known in the field (at least it admitted this and did not write incorrectly that very little research has been done on motivation in Asia). Although the paper was statistically sophisticated, it was still telling a well-known story and little else. Authors are surprised when a solid paper such as this is rejected, but it is very important that they clearly state the contributions to theory, empirical evidence, and practice. ${ }^{1}$ Authors should not make reviewers guess their contributions. Moreover, papers that utilize theory and methods from other business or social science fields are potentially acceptable at $A P J M$, but it is important that theory and evidence relevant to scholars of management and organizations are addressed (e.g., Aaker, 2007; Davidsson \& Wiklund, 1997; Huang, Chen, \& Kao, 2012; Raman \& Fisher, 1996).

Additional guidance on theory contributions is available from a number of fine works in management (e.g., Colquitt \& Ireland, 2009; Corley \& Gioia, 2011; Van de Ven, 2007; Whetten, 1989). For contributions to practice, some good works include Bartunek and Rynes (2010), Christensen and Raynor (2003), and Peng and Dess

\footnotetext{
${ }^{1}$ Not all papers will have contributions to empirical or case evidence. Conceptual or review papers' primary contributions will be to theory with perhaps some small, potential contributions to practice in management and organizations (Ahlstrom, 2011c; Ahlstrom, Chen, \& Yeh, 2010).
} 
(2010). Helpful examples of empirical contributions (as well as others) can be found in many papers in APJM and other business journals (Beny, 2007; Jiang \& Peng, 2011). Also see Ahlstrom (2011c), Law, Wong, Huang and Li (2008), Meyer et al. (2009), Peng, Li, Xie, and Su (2010), and Rynes et al. (2005), for some helpful examples. Contributions, particularly those to theory and practice, should provide actionable insights for interested readers to build, test, and improve theory, research, and practice in the field of management and organizations (Ahlstrom, 2011c; Ahlstrom, Lamond, \& Ding, 2009; Bhagat et al. 2010; Fang, 2010; Rynes, 2002).

\section{Special issue: Leadership in Asia}

Professors Rico Lam, Xu Huang, and Dora Lau guest edited this Special Issue of $A P J M$. The articles that follow were chosen from among those submitted and presented at the APJM Special Issue Conference on Leadership in Asia in December 2010, right before the biennial Asia Academy of Management conference, both of which were hosted by the University of Macau.

\section{References}

Aaker, D. 2007. Innovation: Brand it or lose it. California Management Review, 50(1): 8-24.

Abrahamson, E. 2008. 22 things I hate: Mini rants on management research. Journal of Management Inquiry, 17(4): 422-425.

Ahlstrom, D. 2010a. Publishing in the Asia Pacific Journal of Management. Asia Pacific Journal of Management, 27(1): 1-8.

Ahlstrom, D. 2010b. Clearing the first hurdle at the Asia Pacific Journal of Management. Asia Pacific Journal of Management, 27(2): 171-177.

Ahlstrom, D. 2010c. Avoiding common missteps: Writing papers suitable for the Asia Pacific Journal of Management. Asia Pacific Journal of Management, 27(4): 583-586.

Ahlstrom, D. 2011a. On the aims and scope of the Asia Pacific Journal of Management: What does APJM really seek to publish?. Asia Pacific Journal of Management, 28(2): 215-219.

Ahlstrom, D. 2011b. A checklist for prospective authors of Asia Pacific Journal of Management. Asia Pacific Journal of Management, 28(3): 449-452.

Ahlstrom, D. 2011c. Some helpful sources for prospective authors in Asia Pacific Journal of Management. Asia Pacific Journal of Management, 28(4): 661-665.

Ahlstrom, D. 2012. On the types of papers the Asia Pacific Journal of Management generally publishes. Asia Pacific Journal of Management, 29(1): 1-7.

Ahlstrom, D., Chen, S.-j., \& Yeh, K. S. 2010. Managing in ethnic Chinese communities: Culture, institutions, and context. Asia Pacific Journal of Management, 27(3): 341-354.

Ahlstrom, D., Lamond, D., \& Ding, Z. 2009. Reexamining some management lessons from military history. Asia Pacific Journal of Management, 26(4): 617-642.

Bartunek, J. M., \& Rynes, S. L. 2010. The construction and contributions of implications for practice: What's in them and what might they offer?. Academy of Management Learning \& Education, 9: 100-117.

Beny, L. 2007. Insider trading laws and stock markets around the world: An empirical contribution to the theoretical law and economics debate. Journal of Corporate Law, 32: 237-300.

Bhagat, R. S., McDevitt, A. S., \& McDevitt, I. 2010. On improving the robustness of Asian management theories: Theoretical anchors in the era of globalization. Asia Pacific Journal of Management, 27(2): $179-192$.

Christensen, C. M., \& Raynor, M. E. 2003. Why hard-nosed executives should care about management theory. Harvard Business Review, 81(9): 66-74.

Colquitt, J. A., \& Ireland, R. D. 2009. From the editors: Taking the mystery out of AMJ's reviewer evaluation form. Academy of Management Journal, 52(2): 224-228. 
Corley, K. G., \& Gioia, D. A. 2011. Building theory about theory building: What constitutes a theoretical contribution?. Academy of Management Review, 36(1): 12-32.

Cummings, L. L., \& Frost, P. J. (Eds.). 1985. Publishing in the organizational sciences. Homewood, IL: Irwin.

Cummings, L. L., \& Frost, P. J. (Eds.). 1995. Publishing in the organizational sciences, 2nd ed. Thousand Oaks, CA: Sage.

Davidsson, P., \& Wiklund, J. 1997. Values, beliefs and regional variations in new firm formation rates. Journal of Economic Psychology, 18: 179-199.

Fang, T. 2010. Asian management research needs more self-confidence: Reflection on Hofstede (2007) and beyond. Asia Pacific Journal of Management, 27(1): 155-170.

Huang, Y., Chen, A., \& Kao, L. 2012. Corporate governance in Taiwan: The nonmonotonic relationship between family ownership and dividend policy. Asia Pacific Journal of Management, 29(1): 39-58.

Huff, A. S. 1999. Writing for scholarly publication. Thousand Oaks, CA: Sage.

Huff, A. S. 2008. Designing research for publication. Thousand Oaks, CA: Sage.

Jiang, Y., \& Peng, M.W. 2011. Are family ownership and control in large firms good, bad, or irrelevant? Asia Pacific Journal of Management, 28(1): 15-39.

Kilduff, M. 2007. Editor's comments: The top ten reasons why your paper might not be sent out for review. Academy of Management Review, 32: 700-702.

Law, K. S., Wong, C.-S., Huang, G.-H., \& Li, X. 2008. The effects of emotional intelligence on job performance and life satisfaction for the research and development scientists in China. Asia Pacific Journal of Management, 25(1): 51-69.

Meyer, K. E., Estrin, S., Bhaumik, S., \& Peng, M. W. 2009. Institutions, resources, and entry strategies in emerging economies. Strategic Management Journal, 30(1): 61-80.

Peng, M. W., \& Dess, G. G. 2010. In the spirit of scholarship. Academy of Management Learning \& Education, 9(2): 282-298.

Peng, M. W., Li, Y., Xie, E., \& Su, Z. 2010. CEO duality, organizational slack, and firm performance in China. Asia Pacific Journal of Management, 27(4): 611-624.

Raman, A., \& Fisher, M. 1996. Reducing the cost of demand uncertainty through accurate response to early sales. Operations Research, 44(4): 87-99.

Rynes, S. L. 2002. From the editors: Some reflections on contribution. Academy of Management Journal, 45: 311-313.

Rynes, S. L., Hillman, A., Ireland, R. D., Kirkman, B., Miller, C. C., Rajagopalan, N., \& Shapiro, D. 2005. From the editors: Everything you've always wanted to know about AMJ (but may have been afraid to ask). Academy of Management Journal, 48(5): 732-737.

Van de Ven, A. H. 2007. Engaged scholarship: A guide for organizational and social research. Oxford: Oxford University Press.

Whetten, D. A. 1989. What constitutes a theoretical contribution?. Academy of Management Review, 14(4): $490-495$.

David Ahlstrom ( $\mathrm{PhD}$, New York University) is a professor at The Chinese University of Hong Kong. His research interests include managing in Asia, innovation and entrepreneurship, and management and organizational history. Professor Ahlstrom has published over 75 peer-reviewed articles in journals such as the Strategic Management Journal, Academy of Management Review, Journal of International Business Studies, Academy of Management Perspectives, and the Journal of Management Studies. His work has also appeared on multiple occasions in The Wall Street Journal. Professor Ahlstrom co-authored the textbook International Management: Strategy and Culture in the Emerging World and guest edited two Special Issues of Entrepreneurship: Theory \& Practice. Professor Ahlstrom has also guest edited two Special Issues of APJM: Turnaround in Asia in 2004 and Managing in Ethnic Chinese Communities in 2010, and was Senior Editor of $A P J M$ during 2007-2009, before serving as APJM Editor-in-Chief from 2010-2012. 